
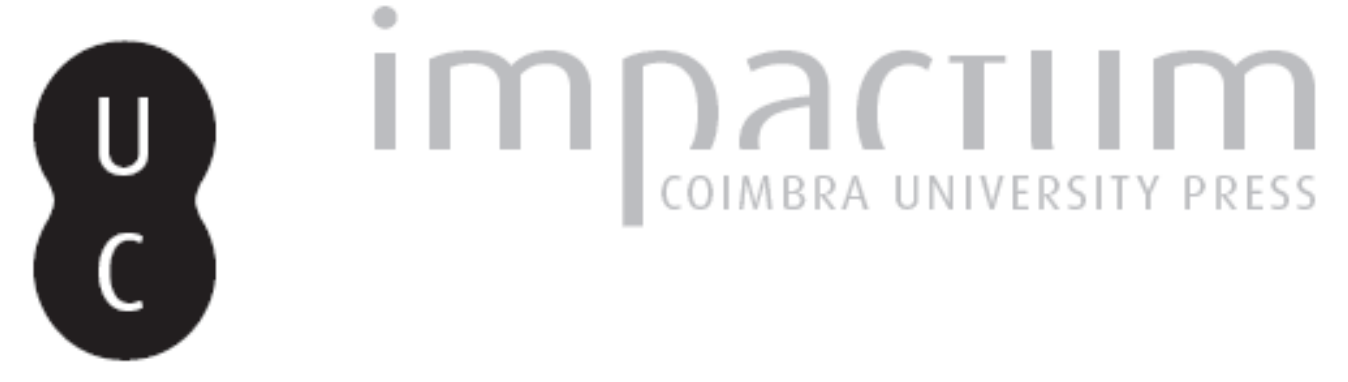

\title{
A Regra do Templo ou o esplendor da arte militar medieval
}

\section{Autor(es): $\quad$ Monteiro, João Gouveia}

Publicado por: Centro de História da Sociedade e da Cultura

URL persistente:

URI:http://hdl.handle.net/10316.2/39475

DOI:

DOI:http://dx.doi.org/10.14195/1645-2259_11_1

Accessed : $\quad$ 26-Apr-2023 10:45:36

A navegação consulta e descarregamento dos títulos inseridos nas Bibliotecas Digitais UC Digitalis, UC Pombalina e UC Impactum, pressupõem a aceitação plena e sem reservas dos Termos e Condições de Uso destas Bibliotecas Digitais, disponíveis em https://digitalis.uc.pt/pt-pt/termos.

Conforme exposto nos referidos Termos e Condições de Uso, o descarregamento de títulos de acesso restrito requer uma licença válida de autorização devendo o utilizador aceder ao(s) documento(s) a partir de um endereço de IP da instituição detentora da supramencionada licença.

Ao utilizador é apenas permitido o descarregamento para uso pessoal, pelo que o emprego do(s) título(s) descarregado(s) para outro fim, designadamente comercial, carece de autorização do respetivo autor ou editor da obra.

Na medida em que todas as obras da UC Digitalis se encontram protegidas pelo Código do Direito de Autor e Direitos Conexos e demais legislação aplicável, toda a cópia, parcial ou total, deste documento, nos casos em que é legalmente admitida, deverá conter ou fazer-se acompanhar por este aviso.

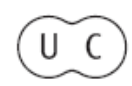




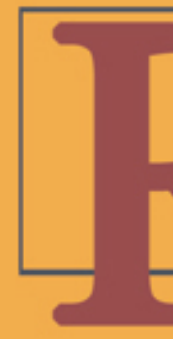

\section{evista de História} da Sociedade e da Cultura

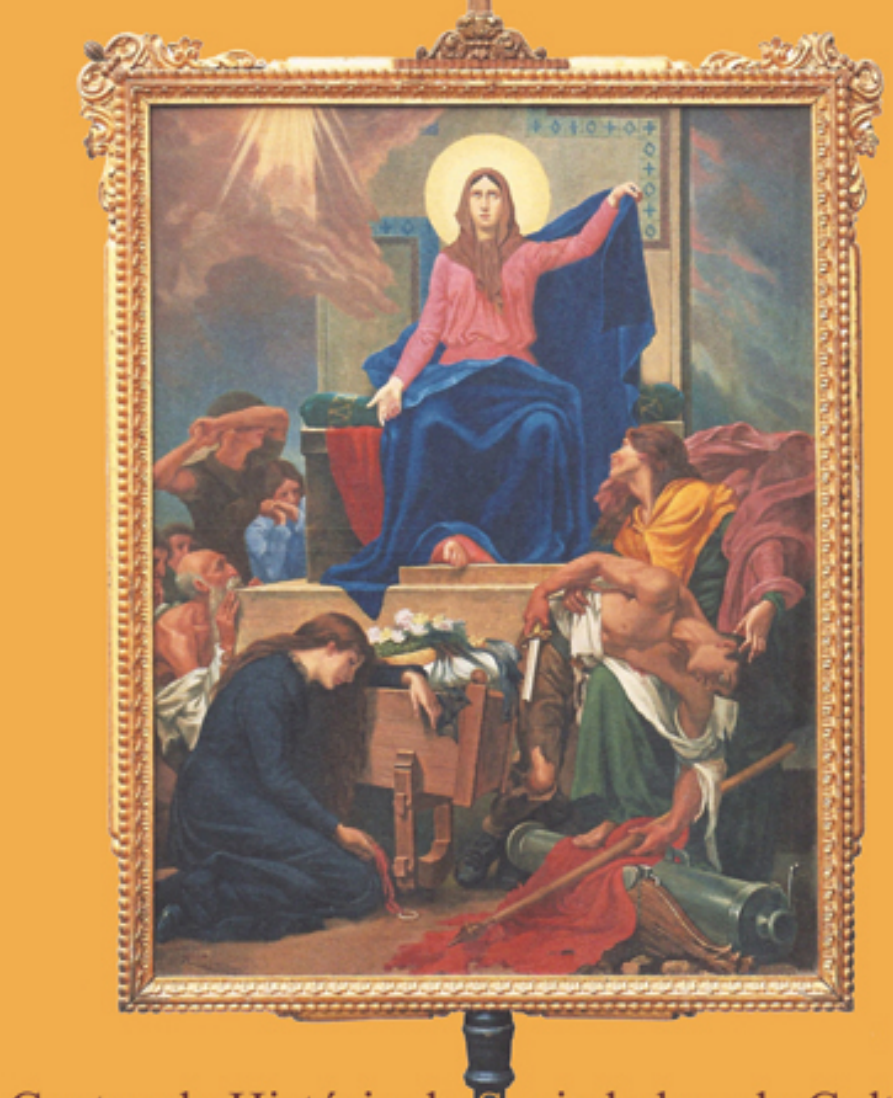

Centro de História da Sociedade e da Cultura Universidade de Coimbra 


\title{
A Regra do Templo ou o Esplendor da Arte Militar Medieval
}

\author{
João Gouveia Monteiro \\ Universidade de Coimbra \\ Centro de História da Sociedade e da Cultura da Universidade de Coimbra \\ jgmonteiro@mail.telepac.pt \\ Texto recebido em/ Text submitted on: 22/01/2011 \\ Texto aprovado em/ Text approved on: 20/06/2011
}

\section{Resumo/Abstract:}

Pretende-se com este trabalho fornecer ao estudioso da arte militar medieval uma ferramenta, um guia de trabalho. Trata-se de apresentar de uma maneira simples e funcional aquele que é um dos escritos militares originais mais importantes de toda a Idade Média: a Regra do Templo. Especialistas na defesa da Terra Santa, os Templários, surgidos em 1120 e legitimados (com o apoio de S. Bernardo de Claraval) no Concílio de Troyes de 1129, desenvolveram formas de organização e de conduta marcial que não encontram paralelo na Europa do seu tempo. Esses procedimentos encontram-se reunidos na Regra do Templo, originalmente redigida em latim mas de que rapidamente foi feita uma tradução francesa, para utilização prática pelos freires. Este estudo apresenta de forma sistematizada e muito resumida os princípios militares mais importantes contidos na Règle du Temple: a hierarquia militar; os acampamentos de campanha; as colunas de marcha; os esquadrões de combate; o processo de carga da cavalaria; o equipamento militar; a manutenção dos cavalos e das armas; o treino militar; e o quadro das infracções militares e das respectivas punições.

This paper aims to provide to the studious of medieval warfare a tool, a guide of work. It tries to present in a simple and operating way one of the most original and important militaries pieces of writing of the whole Middle Ages: the Rule of the Templars. Specialists in the defence of the Holy Land, the Templars, appeared in 1120 and legitimated (with the support of Saint Bernard of Claraval) in council of Troyes in 1129, developed manners of organization and martial conducts without parallelism in Europe of it's time. These procedures are compiled in the Rule of the Templars, which was originally written in Latin but quickly translated to French, to be easily used by the friars. This work presents in a systematized and very resumed way the most important military principles included in the Règle du Temple: the military hierarchy; the camps during the campaigns; the marching columns; the fighting squadrons; the procedure of the cavalry's charge; the military equipment; the maintenance of horses and arms; the military training; and the table of the military infractions and it's punishments.

Palavras chave/Keywords:

Templários; Terra Santa; Guerra Medieval; Regra do Templo.

Templars; Holy Land; Medieval warfare; the Rule of the Templars. 


\section{Introdução ${ }^{1}$}

Segundo explica Guilherme de Tiro (arcebispo de Tiro entre 1175 e 1186 e chanceler do reino de Jerusalém de 1174 a $1184 / 1185^{2}$ ) na sua Historia rerum in partibus transmarinis gestarum (1167-1184), a fundação da Ordem do Templo terá ocorrido nos anos de 1119-1120. Mais provavelmente, segundo Alain Demurger, nos inícios de 1120. O objectivo da nova organização consistia em proteger os peregrinos que chegavam ao Médio Oriente com o objectivo de visitar a Terra Santa. Os perigos em que estes recém-chegados incorriam eram brutais, pois a ladroagem muçulmana, o sol, a sede e os animais selvagens do vale do rio Jordão (p. ex.: os leões) tornavam os acampamentos e as colunas de marcha muito vulneráveis.

A fundação da Ordem do Templo deve-se a um cavaleiro da Champagne, de nome Hugo de Payns ${ }^{3}$. Este já por duas vezes tomara a cruz e acompanhara o seu senhor (o conde de Champagne) à Terra Santa. Em 1114 acabou por decidir permanecer aqui, em contacto com os Cónegos do Santo Sepulcro e como protector (ele e outros cavaleiros cruzados) dos interesses destes, formando uma espécie de confraria. Anos mais tarde, considerando não estarem a ser bem aproveitados pelos ditos Cónegos e com vontade de pronunciar os votos religiosos (de obediência, pobreza e castidade), de viver segundo uma Regra e de combater em defesa da "Terra do Cristo", Hugo e os seus companheiros avançaram para a constituição de uma nova Ordem. Para tanto, receberam o apoio do rei de Jerusalém, Balduíno II, que lhes cedeu o seu palácio, nos anexos da mesquita al-Aqsa, sobre a esplanada

1 Seguiremos, nesta breve apresentação: DEMURGER, Alain - Temple, ordre du, in BÉRIOU, Nicole et JOSSERAND, Philippe - Prier et Combattre. Dictionnaire européen des ordres militaires au Moyen Âge. Librairie Arthème Fayard, 2009, p. 896-902; e UPTONWARD, J. M. - The Rule of the Templars. The French Text of the Rule of the Order of the Knights Templar. Translated and Introduced by J. M. Upton-Ward. Woodbridge: The Boydell Press, 1992 (Introdução: p. 1-17). Para aprofundamentos, veja-se: DEMURGER, Alain Vie et Mort de l'Ordre du Temple. Paris: Seuil, 1989; e BARBER, Malcolm, The new knighthood: a history of the Order of the Temple. Cambridge, 1994.

2 EDBURY, Peter - Guillaume de Tyr, in BÉRIOU, Nicole et JOSSERAND, Philippe - Prier et Combattre..., p. 416-417.

3 Payns é uma aldeia cerca de oito milhas a norte de Troyes, em França, no actual departamento de Aube. 
do Templo, no lugar do antigo palácio de Salomão (daí a designação de Ordem do Templo).

A nova organização - cuja novidade consistia em combinar a figura do monge com a do soldado - cresceu depressa e obteve apoios relevantes. Atraídos por esta configuração original do miles Christi, por esta nova via de salvação proposta aos laicos, os primeiros Templários - proferidos os votos perante o Patriarca de Jerusalém e orientando-se pela Regra de Santo Agostinho, tal como os Cónegos do Santo Sepulcro - suscitaram a simpatia de destacados cavaleiros ocidentais que vieram até à Palestina para se juntar a eles: assim o fizeram Foulques, conde de Anjou (futuro rei de Jerusalém), logo em 1120, e, cinco anos mais tarde, o conde de Champagne, Hugo. Este último manteria relações estreitas com Hugo de Payns e juntou-se à Ordem após ter cedido as suas terras ao sobrinho Teobaldo IV (já conde de Blois) e ter abandonado a sua família. Dado que o ex-conde de Champagne tinha sido generoso para com os Cistercienses, é provável que se deva a Hugo de Champagne uma primeira sensibilização de Bernardo de Claraval (por carta pessoal ou através do rei Balduíno II) para a conveniência da aprovação da nova Ordem.

Em 1127, Hugo de Payns e cinco companheiros seus partiram para o Ocidente e, depois de terem percorrido a Champagne, o Anjou, a Normandia, a Inglaterra e até a Escócia, encaminharam-se para Troyes a tempo de assistirem à abertura de um Concílio Provincial que se haveria de revelar decisivo. O Concílio abriu a 13 de Janeiro de 1129, sob a direcção do legado pontifical Mateus d'Albano e com a participação dos bispos de Sens e de Reims, para além de muitos abades das grandes casas cistercienses da Champagne e da Borgonha. A presença de amigos influentes garantiu uma boa receptividade à exposição do pequeno grupo de Templários e o concílio concebeu e aprovou a Regra da nova Ordem. Para acalmar os espíritos receosos do que poderia resultar de uma organização de freires-cavaleiros, e também para justificar a respectiva acção na Terra Santa, o próprio Bernardo de Claraval tratou de redigir um texto de elogio e recomendação da nova milícia: o De laude Novae Militiae ad Milites Templi. Com tais apoios, os ânimos serenaram e a Ordem do Templo foi aceite nas mais altas instâncias eclesiásticas, ficando colocada sob a autoridade directa do Papa (Honório II) 
Hugo de Payns regressou ao Médio Oriente em meados de 1129, mas não sem deixar no Ocidente um conjunto de irmãos que se encarregariam de receber um número crescente de doações e de comprometimentos pessoais. Sobretudo nas regiões da Champagne e da Borgonha, mas também da Provença, do Languedoc e da Península Ibérica, zonas onde o entusiasmo no seio da pequena e da média nobrezas perante este novo projecto se revelou mais forte. Nos finais da década de 1130, a Ordem do Templo dispunha já de uma estrutura hierarquizada e capaz, resultado também do esforço de Roberto de Craon, que em 1136 substituíra Hugo de Payns no cargo de Mestre. Em 1139, foi a vez de o Papa Inocêncio II promulgar a bula Omne datum optimu, que criou os freires-capelães (uma nova categoria dentro da Ordem, um grupo separado e com privilégios especiais, que ouvia os irmãos em confissão e os podia absolver).

Como é óbvio, a presença dos Templários na Terra Santa foi essencial à acção dos exércitos cruzados que chegavam com a missão de defender ou (a partir de finais de 1187) de recuperar Jerusalém. O seu bom conhecimento do terreno, dos costumes e da política local e a experiência militar acumulada tornavam os Templários no principal apoio à causa cristã nos difíceis campos da Síria-Palestina. Na década de 1170, os cavaleiros do Templo seriam cerca de 300 no reino de Jerusalém. Eles e os Hospitalários (i.é, os freires da Ordem dos Hospitalários de S. João de Jerusalém, fundada também na Terra Santa, escassos anos antes da Ordem do Templo) equivaleriam a perto de $50 \%$ da capacidade efectiva de combate do reino de Jerusalém; no principado de Antioquia e no condado de Tripoli a situação seria comparável.

Até à queda da fortaleza de S. João de Acre, em 1291, Templários e Hospitalários cumpririam um papel fulcral, não só militar (com carácter de permanência, ao contrário dos exércitos cruzados, que depressa regressavam ao Ocidente) mas também político e até diplomático na gestão dos territórios e castelos dos Estados Latinos do Oriente. Ambas as Ordens tinham, além disso, Casas espalhadas um pouco por toda a Europa, o que lhes garantia uma capacidade ímpar para canalizar financiamentos e para repor efectivos. Graças a isso, os Templários e os Hospitalários conseguiam recuperar rapidamente dos maiores desastres militares, como p. ex. o sofrido em La Forbie, em Outubro de 1244, face ao sultão mameluco Baybars. A partir de 1291, porém, perdida a Terra Santa, Templários e Hospitalários seguiriam 
rumos diferentes. Estes últimos fixar-se-iam em Rodes e, mais tarde (após o cerco de 1522 por Solimão-o-Magnífico), em Malta. Pelo seu lado, os Templários reorganizaram-se no Chipre. Por pouco tempo, porém: em 13 de Outubro de 1307, todos os freires do Templo do reino de França seriam detidos por ordem do rei Filipe-o-Belo. Seguir-se-ia o longo 'processo dos Templários', que levaria à extinção da Ordem em 1312, no Concílio de Viena.

A Ordem do Templo foi a primeira de todas as Ordens Religiosas Militares a dispor de uma Regra ${ }^{4}$. O texto original foi redigido em latim, no âmbito do Concílio de Troyes e sob a influência de Bernardo de Claraval (pelo que são numerosas as referências aos bons costumes e à conduta moral). Infelizmente, do texto latino conhecem-se apenas seis redacções, todas elas tardias. Isso dever-se-á a dois factos: por um lado, à destruição dos originais aquando da detenção dos Templários em França; por outro, porque - ao contrário dos Hospitalários - os responsáveis pela Ordem do Templo colocaram sempre reservas a uma ampla circulação da sua Regra, como forma de preservar a identidade dos seus princípios e para diminuir o risco de difusão entre os inimigos da Cristandade dos preceitos militares mais importantes.

Escassos anos após o Concílio de Troyes, foi feita uma tradução francesa da Regra do Templo, a qual se conservou até hoje na sua forma original. Não se conhece a data exacta desta tradução, mas é certo que ela se realizou entre 1135 (data do Concílio de Pisa) e 1147. Mais provavelmente entre 1139 (data da citada bula de Inocêncio II) e 1147 (ano da permissão concedida aos freires-cavaleiros para inscrever no seu manto branco uma cruz vermelha).

Em relação à versão latina, a Règle du Temple apresenta algumas nuances interessantes, que denunciam uma certa evolução dos costumes e da política. Por exemplo, são agora autorizados os contactos com os excomungados, como forma de alargar a rede da Ordem e facilitar a incorporação. O mais importante, porém, é perceber a razão de ser de uma versão francesa tão

\footnotetext{
4 A segunda seria a Ordem do Hospital, tendo a Regra sido redigida sob o magistério do Mestre Raymond du Puy e confirmada no final do pontificado do Papa Eugénio III (1145-1153). Cf. TOOMASPOEG, Kristjan - Règle, in BÉRIOU, N. et JOSSERAND, Ph. - Prier et Combattre..., p. 773.
} 
precoce. A explicação é simples: a maioria dos freires-cavaleiros não entendia o latim... Ou seja, foi uma necessidade prática, a de tornar um texto com propósitos de instrução moral e militar acessível na linguagem falada dos monges, que levou ao aparecimento da tradução francesa escassos anos após a redacção da versão original. Tal deve ter sucedido durante o Mestrado de Roberto de Craon (1136-1149).

Em ambas as versões (latina e francesa), a primitiva Regra do Templo abre com um Prólogo de cinco secções: um verdadeiro apelo à "milícia de Cristo", completado por uma lista dos prelados que participaram no Concílio de Troyes. Seguem-se c. 70 artigos (cuja ordem difere ligeiramente da versão latina para a versão francesa) sobre a vida do convento, a liturgia, as faltas e as suas penitências. Esta Regra Primitiva incorpora diversos elementos da Regra de S. Bento e numerosas disposições normativas cistercienses. Ou seja, por influência manifesta de Bernardo de Claraval, afasta-se da Regra de S. Agostinho que tinha norteado os primeiros tempos de acção do grupo de Hugo de Payns na Terra Santa, em articulação com os Cónegos do Santo Sepulcro.

É sabido que tanto a Regra do Templo como a Regra do Hospital influenciaram as Regras de Ordens Militares posteriores, como é o caso dos Teutónicos. Em quase todas elas se nota, entretanto, que os textos primitivos foram sendo acrescentados e, em certa medida, viram aqui e ali o seu espírito ser alterado com a introdução de Estatutos, de "Retrais" (Estatutos Hierárquicos alusivos aos principais cargos dentro da Ordem) e de Definições que a prática diária e a experiência acumulada recomendavam que fossem acrescentados ao texto original, por vezes bastante simplista. Assim, os textos matriciais foram muitas vezes completados ou até, em alguns aspectos, reescritos no sentido de uma menor rigidez e de uma menos acentuada submissão às prescrições litúrgicas ${ }^{5}$.

Em todas as Regras de Ordens Militares é afirmada a necessidade do triplo voto (castidade, obediência e pobreza), mas também da solidariedade e da coesão internas, assim como a recusa de qualquer intromissão externa. Ao mesmo tempo, afirma-se um código de honra próprio e prescreve-se a

5 TOOMASPOEG, Kristjan - Règle, in BÉRIOU, N. et JOSSERAND, Ph. - Prier et Combattre..., p. 774. 
modéstia comportamental, sem exageros nem sequer de natureza religiosa. Pela leitura destes textos, percebe-se que a condição de vida dos freires das Ordens Religiosas Militares se situava a meio-caminho entre a dos monges e a dos cónegos regulares, defendendo-se a frugalidade na alimentação e no conforto individual e colectivo. Também as hierarquias militares são claramente definidas (em especial entre os Templários e os Hospitalários), assim como as subdivisões geográficas resultantes da disseminação das Ordens por vastos espaços territoriais. Nem sempre, porém, a eleição do Mestre e a admissão de novos freires se encontrava claramente regulamentada na versão original das Regras, motivo pelo qual os Estatutos de algumas delas preenchem essas lacunas. Em todas as Regras é dedicado muito espaço a matérias disciplinares, como faltas e penitências (castigos corporais, expulsões, etc.). No caso da Regra do Templo, a hierarquia e a disciplina interna ocupam mesmo um lugar de destaque (e não tanto a atenção aos pobres e aos doentes, como sucede na Regra dos Hospital). Os Templários eram também mais rigorosos na sua recusa de contacto dos freires com pessoas do sexo oposto, o que ajuda a explicar por que motivo o Templo não dispôs de um ramo feminino .

É difícil dizer qual o papel que as Regras desempenhavam na vida quotidiana dos monges. Há quem defenda que esse papel era mais simbólico do que real, assumindo a Regra o valor de uma referência (quase sagrada). Algumas das suas normas seriam até impossíveis de aplicar rigorosamente: no Oriente, devido à ameaça constante da guerra (que se compadecia mal com jejuns e com outros rigores comportamentais); no Ocidente, em resultado de um por vezes reduzido número de freires ${ }^{7}$.

Como já explicámos, os Templários não estimularam uma ampla difusão da sua Regra. Preferiram promover a organização de extractos e de recolhas de artigos para os seus comendadores de modo a evitarem intromissões externas. A Règle du Temple (versão que utilizaremos neste trabalho ${ }^{8}$ )

6 Idem, ibidem, p. 774-775.

7 Idem, ibidem, p. 775.

8 Servir-nos-emos da edição da Règle du Temple publicada por Upton-Ward, que pelo seu lado utilizou a edição de Henri Cruzon, de 1886, baseada nos Mss. de Paris e de Roma, de finais do séc. XIII ou inícios de XIV (trata-se de manuscritos quase idênticos, devendo derivar de uma mesma fonte), e num Ms. de Dijon, de inícios do séc. XIII (o qual, todavia, só contém a Regra Primitiva e os Estatutos Hierárquicos). Cf. UPTON-WARD, J. M. - 
encontra-se estruturada em sete secções (para além do já citado Prólogo de apelo à "milícia de Cristo" e alusivo ao Concílio de Troyes): i) a Regra Primitiva; ii) os Estatutos Hierárquicos (com destaque para os "Retrais", ou seja, os Estatutos específicos dos vários oficiais da Ordem, provavelmente compilados na década de 1160, com base nos Capítulos Gerais dos anos precedentes); iii) as Penitências; iv) a Vida Conventual; v) a realização de Capítulos Ordinários; vi) os Detalhes Suplementares sobre Penitências; vii) e a Recepção [de novos membros] na Ordem. Frisamos que se trata de um texto não homogéneo, que foi sendo aperfeiçoado ao longo de mais de século e meio (entre o Concílio de Troyes e a detenção dos Templários) e que, por isso, incorpora numerosos acrescentos, executados sem uma revisão global do conjunto do texto, o que explica a presença de numerosas repetições. O estilo é bastante prático e vivido, não se tratando de um documento teórico ou abstracto. Com excepção da Regra Primitiva (redigida pelo escriba Jean Michel, segundo identificação do próprio por ordem do Concílio de Troyes e do "venerável irmão Bernardo, abade de Claraval") não se conhece(m) o(s) autor(es) dos diversos textos e acrescentos. Mas é evidente a sua ligação orgânica à Ordem.

A Regra Primitiva da Règle du Temple não apresenta matéria com interesse do ponto de vista militar. Resulta das decisões do Concílio de Troyes, embora reflicta as práticas que vinham do tempo da fundação da Ordem, nove anos antes, na Terra Santa. Contém cerca de 30 cláusulas que são directamente importadas da Regra de S. Bento e inclui também uma decisão de Capítulo Geral da Ordem. Apresenta diversas citações bíblicas, no que contrasta com o resto do documento, bastante mais informal.

Os Estatutos Hierárquicos datam de c. 1165, sendo seguramente anteriores à queda de Jerusalém em finais de 1187 (o que levou ao desaparecimento do cargo de Comandante da Cidade Santa e também do precioso símbolo da Vera Cruz). Nesta secção abordam-se assuntos como: a hierarquia da Ordem; preceitos gerais da vida conventual, militar e religiosa; as armas e os equipamentos; os deveres e privilégios de todos os oficiais e irmãos; etc. Apresenta alguns ajustamentos em relação à Regra Primitiva.

The Rule of the Templars.... Para o que se segue, veja-se a Introdução de Upton-Ward a este trabalho (p. 11-16). 
Nos "retrais" de cada oficial, discrimina-se o número de cavalos, de serventes e de escudeiros de cada líder Templário e o respectivo equipamento. Também se explica como instalar um acampamento, como agir durante uma marcha ou como proceder durante uma carga a cavalo. Há ainda alguns artigos (deslocados) sobre refeições e sobre a morte do Mestre e a eleição do seu sucessor.

As Penitências compõem uma secção que deve ser coeva dos Estatutos Hierárquicos. Aqui se enunciam as várias penas possíveis e se explicitam os nove casos disciplinares que podem conduzir à expulsão, assim como as 31 faltas que podem levar à perda temporária do hábito. Evocam-se também as 10 sentenças possíveis de proferir (da expulsão à absolvição), tal como os deveres dos capelães e a forma como eles devem ser tratados.

Na secção sobre a Vida Conventual encontramos a regulação do dia-a-dia dos freires: as refeições; o levantar e deitar; a disciplina e obediência; as relações pessoais; os jejuns; o comportamento em campanha; etc. Poderá, ou não, tratar-se de normas anteriores aos Estatutos Hierárquicos.

Na quinta secção, sobre os Capítulos Ordinários, trata-se sobretudo dos procedimentos a adoptar durante estas reuniões e no que toca ao código penal da Ordem. Repete-se a lista das penitências e as razões que podem conduzir à expulsão (nelas se incluindo agora a sodomia). É enfatizada a importância de emitir sentenças adequadas e de, para tanto, escutar a opinião dos mais velhos. A revisão destes aspectos sugere uma data de redacção posterior, mas ainda pode ser anterior a 1187.

A penúltima secção compila alguns Detalhes Suplementares sobre Penitências e deve ter sido composta entre 1257 (data da invasão tártara, já mencionada) e 1268 (data da perda de Baghras, ainda não referida). Desenvolve e amplifica as regras incluídas nas secções anteriores: expulsões; casos de perda do hábito; tipos de sentença; etc.

Finalmente, a secção dedicada à Recepção de novos membros funciona como uma espécie de Apêndice sobre a admissão na Ordem: recepção, cerimónia, perguntas, promessas, etc. Só entrava na Ordem do Templo, como freire-cavaleiro, aquele que fosse filho legítimo de cavaleiro e que tivesse linhagem cavaleiresca. No momento da colocação do manto sobre os ombros, eram lidos ao novo freire alguns dos costumes da Ordem e o recruta era aconselhado a informar-se do resto junto dos outros irmãos. 
Em síntese, a Règle du Temple apresenta-se como um conjunto de regulamentos que denunciam o intenso conhecimento da realidade templária e o forte profissionalismo militar de quem os redigiu ${ }^{9}$. Vale por isso a pena observá-la mais de perto, no que aos seus ensinamentos bélicos diz respeito.

\section{A Regra do Templo e a organização da guerra ${ }^{10}$}

\section{A Hierarquia Militar}

1.1. O MESTRE. O Mestre tem o controlo geral da estratégia, embora careça do consentimento do Capítulo da Ordem para tomar as decisões mais relevantes ${ }^{11}$. Segundo os Estatutos Hierárquicos (§ 77-98, pp. 39-44), o Mestre tem direito a ter (para além de um capelão, de um clérigo com três cavalos, de um ferrador, de um escriba sarraceno para servir de intérprete e de um cozinheiro): quatro cavalos; um sargento com dois cavalos; um valete com um cavalo (e com escudo e lança, podendo o Mestre torná-lo cavaleiro ao fim de algum tempo); um turcópolo ${ }^{12}$; dois peões; e um cavalo "turcoman"13 (guardado na caravana). Quando o Mestre cavalga de um lugar para outro, o turcoman deve ser conduzido por um escudeiro e guiado por um cavalo da caravana; e, na guerra, pode conservá-lo na 'corda' (i.é, juntamente

9 BENNETT, Matthew - La Règle du Temple as a Military Manual or How to Deliver a Cavalry Charge, in UPTON-WARD, J. M. - The Rule of the Templars. The French Text of the Rule of the Order of the Knights Templar..., Appendix, p. 175.

${ }^{10}$ Todas as referências ao articulado da Règle du Temple remetem para a edição a cargo de UPTON-WARD, J. M. - The Rule of the Templars. The French Text...

${ }^{11}$ BENNETT, M. - La Règle du Temple as a Military Manual..., p. 178.

${ }^{12}$ Turcople: literalmente, "filho de turco". Guilherme de Tiro chamou aos turcópolos "equites levis armaturae", i.é, cavaleiros levemente equipados. Trata-se de gente que aparece no exército bizantino ao tempo de Aleixo I (1081-1118) como Turcos convertidos ao Cristianismo e conservando os seus modos de combate, mas que estiveram depois presentes em todos os Estados francos (sobretudo como arqueiros a cavalo, muito usados em guarnições de castelos ou em missões de policiamento e de reconhecimento ou ainda para transporte de mensagens). Parecem ter sido sempre recrutados entre os muçulmanos convertidos ao Cristianismo. Cf. RICHARD, Jean - Turcoples, in BÉRIOU, N. et JOSSERAND, Ph. - Prier et combattre..., p. 937.

${ }^{13}$ Turcoman: cavalo de elite, próprio para equitação ou passeio (UPTON-WARD, The Rule of the Templars..., n. 77.3, p. 39). 
com os seus outros cavalos). O Mestre, quando se desloca, também pode ter quatro cavalos de carga e dois cavaleiros como fiéis companheiros. O Mestre não pode principiar uma guerra nem celebrar uma trégua sem o consentimento do convento. O Mestre também não pode pôr Comandantes (p. ex.: Senescal, Marechal, etc.) nas Casas do Templo nos diversos reinos sem a autorização do capítulo. Quando sai do reino de Jerusalém, o Mestre pode deixar o Comandante da Terra ou outro irmão em seu lugar; mas não deve enviar nenhum irmão para as terras de Antioquia ou de Tripoli em seu lugar, com poder sobre os Comandantes que aí estão, excepto para averiguar, para aconselhar ou para ver as guarnições dos castelos. O Mestre não pode admitir irmãos sem o consentimento do capítulo. Quando sucede, em tempo de guerra, que os irmãos estão em armas no campo, o Mestre pode tomar seis, oito ou até 10 freires cavaleiros para o acompanhar.

1.2. O SENESCAL. Posiciona-se abaixo do Mestre e assegura a administração das terras, das Casas, da comida e do trem de apoio. Compete-lhe segurar o "gonfanon baucon" - a bandeira que constitui o símbolo do Templo e seu estandarte em batalha. Trata-se de um oficial senior, que era por vezes eleito para Mestre ${ }^{14}$. Segundo os Estatutos Hierárquicos ( $\$ 99$ -100 , p. 44), o Senescal pode ter quatro cavalos, uma mula ou palafrém, dois escudeiros, um sargento com dois cavalos, um turcópolo com um cavalo, um escriba sarraceno com um cavalo, dois peões e um freire-cavaleiro como companheiro acompanhado de quatro cavalos e dois escudeiros. Leva o mesmo selo (bolle) que o Mestre e carrega a bandeira-malhada ${ }^{15}$ e uma tenda redonda (tal como o Mestre). Quando o Mestre está ausente, o Senescal ocupa o seu lugar e comanda todo o equipamento das terras e das Casas, todas as Casas e toda a comida.

1.3. O MARECHAL. Este oficial tem funções relevantes ao nível da distribuição de todo o equipamento militar aos cavaleiros e também aos sargentos. Compete ao Marechal supervisionar a distribuição das montadas, bem como a respectiva substituição (por defeito ou por se terem perdido

${ }^{14}$ BENNETT, M. - La Règle du Temple..., p. 178-179.

${ }^{15}$ A bandeira dos Templários era um pendão de duas pontas dividido horizontalmente, com branco em cima e preto em baixo (UPTON-WARD, The Rule of the Templars..., n. 99.1, p. 44). 
em batalha $)^{16}$. Segundo os Estatutos Hierárquicos (§ 101-109, pp. 44-46), o Marechal pode ter quatro cavalos e dois escudeiros, uma mula ou um bom turcoman, um sargento com um cavalo e um turcópolo com um cavalo. Deve ter sob o seu comando todas as armas da Casa (compradas, oferecidas, doadas ou obtidas como despojo), com excepção das bèstas (que devem ser entregues ao Comandante da Terra) e das armas turcas (que os Comandantes compram para dar aos irmãos sargentos artesãos que estão sob o seu comando). O Marechal deve dar ordens e formar os irmãos onde quer que seja necessário. Pode comprar cavalos ou mulas de ambos os sexos. Quando ele está na terra de Tripoli ou de Antioquia, o Comandante pode, se quiser, dar-lhe o Marechalato dessa terra. O Marechal do convento pode indicar o Sub-Marechal e o Porta-Estandarte, sob conselho. Deve chamar os irmãos às armas e dar-lhes ordens onde quer que esteja 0 Mestre (ou alguém por ele).

\subsection{O COMANDANTE DA TERRA DE JERUSALÉM E DO REINO} DE JERUSALÉM. Cabe-lhe zelar pelos bens da Ordem. Supervisiona os cavalos, os rebanhos e os animais domésticos. Nas quintas, assegura os alimentos para os cavalos. Distribui os irmãos pelo Templo (em Jerusalém) e pelas Casas e castelos das zonas rurais, de forma a todos poderem ser bem sustentados em tempo de paz ${ }^{17}$. Segundo os Estatutos Hierárquicos (§ 110-119, pp. 47-49), o Comandante da Terra de Jerusalém e do Reino de Jerusalém deve ter quatro cavalos, palafrém em vez de mula, dois escudeiros, um sargento com dois cavalos, um turcópolo com um cavalo e dois peões. O Comandante da Terra é o Tesoureiro do convento. Todo o despojo, todos os animais com albardas, todos os escravos e todo o gado doméstico que as Casas do reino de Jerusalém obtêm através da guerra devem ficar sob a autoridade dele, excepto os cavalos de sela, as armas e o equipamento defensivo, os quais são entregues ao Marechal. Todos os barcos que pertencem à Casa de Acre estão sob a autoridade do Comandante da Terra e do Reino de Jerusalém.

1.5. O COMANDANTE DA CIDADE DE JERUSALÉM. É o guardião dos peregrinos que rumam a Jerusalém e, nesse sentido, encarna a função

\footnotetext{
${ }^{16}$ BENNETT, M. - La Règle du Temple..., p. 179.

${ }^{17}$ Idem, ibidem.
} 
original dos cavaleiros do Templo ${ }^{18}$. Ele e o seu séquito pessoal têm funções relevantes de transporte de símbolos preciosos da Ordem e de organização e comando dos freires cavaleiros na ausência do Mestre. Segundo os Estatutos Hierárquicos (§120-124, pp. 49-50), deve ter quatro cavalos, um turcoman ou um bom rocim em vez de mula, dois escudeiros, um sargento com dois cavalos e um turcópolo com um cavalo. Deve ter 10 freires cavaleiros sob o seu comando para guiar e proteger os peregrinos que vêm para o rio Jordão. Enquanto a sua autoridade durar, deve transportar uma tenda redonda e a bandeira ou estandarte malhado. Quando a Vera $\mathrm{Cruz}^{19}$ é transportada a cavalo, o Comandante de Jerusalém e os seus 10 cavaleiros devem guardá-la de dia e de noite, e devem acampar tão perto dela quanto possível (de noite, dois irmãos devem vigiá-la). De todo o despojo obtido através da guerra para além do rio Jordão (o qual pertence ao Comandante do Reino de Jerusalém), o Comandante da Cidade de Jerusalém deve ter metade; e de todo o despojo alcançado do lado de cá do rio não pode ter nada. Todos os cavaleiros seculares que estão em Jerusalém e que estão associados com a Casa devem ir e devem alojar-se junto dele e devem cavalgar debaixo da sua bandeira. Todos os irmãos a viver em Jerusalém, assim como todos os que vão e que vêm enquanto ele aí está e o Marechal está ausente, ficam sob o seu comando.

1.6. OS COMANDANTES DAS TERRAS DE TRIPOLI E DE ANTIOQUIA. Têm responsabilidades comparáveis e sobretudo ao nível do equipamento dos castelos sob o seu comando ${ }^{20}$. Segundo os Estatutos Hierárquicos (§ 125-128, pp. 50-51), devem ter quatro cavalos, palafrém em vez de mula, um sargento com dois cavalos, um turcópolo com um cavalo, um peão e um cavaleiro como companheiro. Todas as pessoas que vivem nas casas dos seus baillies $^{21}$ estão sob o seu comando, tanto em tempo de

${ }^{18}$ Idem, ibidem.

19 A parte [lenho] da Vera Cruz que a Ordem do Templo tinha em seu poder foi capturada pelos muçulmanos na batalha de Hattin, em 1187. Melville conta uma história segundo a qual um Templário escapou com ela e enterrou-a na areia, mas depois, quando voltou para a recuperar, já não conseguiu encontrá-la (UPTON-WARD, The Rule of the Templars..., n. 122.1, p. 49-50).

${ }^{20}$ BENNETT, M. - La Règle du Temple..., p. 180.

${ }^{21}$ Baillie (na Ordem do Templo): entidade territorial e jurisdicional intermédia entre a comenda e a província. Estrutura criada 'aos soluços', em função das necessidades. 
guerra como em tempo de paz. Os Comandantes das Terras de Tripoli e de Antioquia devem abastecer os castelos dos seus baillies com couro, trigo, vinho, ferro, aço e com sargentos para guardar as portas.

1.7. OS IRMÃOS CAVALEIROS COMANDANTES DAS CASAS, E OS COMANDANTES DOS CAVALEIROS. Actuam como oficiais no campo de batalha, sendo-lhes também permitido transportar estandartes (quer como sinal de estatuto, quer como ponto de reagrupamento em batalha $)^{22}$. Segundo os Estatutos Hierárquicos (\$132, p. 52), os Irmão Cavaleiros, Comandantes das Casas, devem ter quatro cavalos e dois escudeiros. Quanto ao Comandante dos Cavaleiros ( $\$ 137$, p. 53), deve estar sob o comando do Comandante da Terra, tanto em tempo de guerra como de paz, na ausência do Marechal (salvo para autorizar os irmãos a que derramem sangue, corram com os cavalos a galope ou nadem).

1.8. OS FREIRES-CAVALEIROS E OS IRMÃOS SARGENTOS DO CONVENTO. Segundo os Estatutos Hierárquicos (§138-144, pp. 53-55), cada freire-cavaleiro do convento deve ter três cavalos e um escudeiro; mas o Mestre poderá conceder-lhe mais um cavalo e um escudeiro. Devem ter as seguintes armas: um hauberk ${ }^{23}$; meia-calça de malha metálica; um elmo ou um chapéu-de-ferro; uma espada; um escudo; uma lança; uma maça turca; uma sobrecota; um gibão; sapatos de malha; e três facas: um punhal, uma faca de pão e uma faca de bolso. Os irmãos sargentos podem ter tudo aquilo que os freires-cavaleiros têm, excepto o equipamento para os cavalos, a tenda e o caldeirão; e podem ter uma cota de malha sem mangas, meia-calça sem pé e um chapéu-de-ferro. Há cinco irmãos sargentos que devem ter dois cavalos e um escudeiro cada um: o Sub-Marechal, o Porta-Estandarte, o Cozinheiro do convento, o Ferrador do convento e o Comandante do estaleiro de Acre ${ }^{24}$; os restantes só podem ter um cavalo (o outro fica ao critério do Mestre). Nenhum irmão pode nadar, derramar

Cf. DEMURGER, Alain - Baillie, in BÉRIOU, N. et JOSSERAND, Ph. - Prier et combattre..., p. 138.

${ }^{22}$ BENNETT, M. - La Règle du Temple..., p. 180.

${ }^{23}$ Hauberk: cota de malha, com coifa a envolver a cabeça e deixando apenas o rosto a descoberto (UPTON-WARD, The Rule of the Templars ..., n. 138.1, p. 53). Cf. também infra: nota 28 .

${ }^{24}$ O Comandante do estaleiro de Acre funcionava como Almirante da frota dos Templários (UPTON-WARD, The Rule of the Templars..., n. 143.1, p. 54). 
sangue, tomar medicamentos, ir à cidade ou cavalgar um cavalo a galope sem autorização.

1.9. O "TURCOPOLIER". É sob o seu comando que se encontram o turcópolos do convento central. Foi, desde o início, um cristão latino, durante muito tempo subordinado ao Marechal. Em situação de guerra, comanda também os sargentos de armas ${ }^{25}$. Segundo os Estatutos Hierárquicos (§ 169-172, p. 61), o Turcopolier deve ter quatro cavalos, e turcoman em vez de mula. Se soar o alarme no alojamento ou no acampamento, não deve sair sem autorização: o Marechal indicar-lhe-á o que deverá fazer. E se tiver de ir a algum lado, deve enviar um ou dois turcópolos para a área onde foi o alarme para ver de que se trata, posto que informará o Marechal. Quando o Turcopolier vai com os batedores e lhe são dados cinco, ou seis, ou oito cavaleiros, ou mesmo 10, estes ficam sob o seu comando. E se forem 10 e houver aí um Comandante dos Cavaleiros com uma bandeira malhada, o Turcopolier fica sob o comando deste. Todos os irmãos sargentos, quando em armas, ficam sob o comando do Turcopolier (mas em tempo de paz isso não sucede). Os turcópolos estão sempre sob o seu comando, em tempo de guerra ou de paz. O Sub-Marechal e o Porta-Estandarte, entre outros, não ficam debaixo do comando do Turcopolier caso não estejam integrados no esquadrão deste.

1.10. O SUB-MARECHAL. Responsável pelo equipamento menor. Subordinado ao Marechal em matéria de equipamento dos freires, comandava todos os irmãos que serviam no Marechalato ${ }^{26}$. Segundo os Estatutos Hierárquicos (§ 173-175, pp. 61-62), deve ter dois cavalos. Deve dar aos irmãos as peças pequenas do equipamento e tê-las carregadas e reparadas, e poderá distribuir selas velhas, mantas de viagem, lanças, espadas, chapéus-de-ferro, armas turcas velhas e bèstas (coisas que pertencem ao Marechalato), chumaços de sela, etc. Os artesãos do Marechalato estão sob o seu comando.

${ }^{25}$ O cargo de "Turcopolier” (ou “Turcoplier”) existia já nos finais do séc. XII, mas só no séc. XIII o podemos apreender com segurança. Os primeiros "Turcopoliers" conhecidos são o Hospitalário Pierre de Sardines (1248) e o Templário Hervis de Lyon (1262). A consideração social por estes oficiais aumentou ao longo do séc. XIII: Thibaut Gaudin, futuro Mestre do Templo, era "Turcopolier" em 1277. Cf. BURGTORF, Jochen - Turcoplier, in BÉRIOU, N. et JOSSERAND, Ph. - Prier et combattre..., p. 938.

${ }^{26}$ BENNETT, M. - La Règle du Temple..., p. 180. 
Quando o Marechal está ausente, o Porta-Estandarte fica também sob o seu comando.

1.11. O PORTA-ESTANDARTE. Segundo os Estatutos Hierárquicos (§ 177-179, pp. 62-63), deve ter dois cavalos. Todos os escudeiros da Casa estão sob o seu comando, qualquer que seja o lugar. Quando o convento está em marcha, o Porta-Estandarte (ou Gonfanonier) deve ir em frente da bandeira e deve encabeçar a coluna. Em tempo de guerra, quando os irmãos avançam em esquadrões, um turcópolo deve conduzir a bandeira e o Porta-Estandarte deve dispor os escudeiros num esquadrão.

1.12. OS IRMÃOS SARGENTOS, COMANDANTES DAS CASAS. Segundo os Estatutos Hierárquicos ( $§ 180$, p. 63), devem ter um cavalo, um escudeiro (recrutado entre os seus sargentos) e um segundo escudeiro (caso o Porta-Estandarte concorde em atribuir-lho).

1.13. OS CASTELÃES DOS CASTELOS. Segundo os Detalhes Suplementares sobre Penitências (§ 633, p. 162) os castelães [i.é, os alcaides] dos castelos estão sob as ordens do Comandantes dos Cavaleiros em batalha (onde este transporta uma bandeira); mas dentro dos castelos já não é assim.

\section{O acampamento militar}

2.1. A MONTAGEM DO ACAMPAMENTO. Quando o Porta-Estandarte estabelece o acampamento, os irmãos devem montar as suas tendas à volta da capela e do lado de fora das cordas, cada qual chegando no seio da sua unidade. Nenhum irmão deve ocupar um lugar antes de ter sido lançado o grito "Acampem, senhores irmãos, em nome do Senhor!" e antes de o Marechal ter ocupado a sua posição (§ 148, Estatutos Hierárquicos, “Como os Irmãos devem Instalar um Acampamento”, p. 56). Quando querem instalar o acampamento, os irmãos não podem erguer três tendas ou mais sem autorização, mas podem erguer duas ( $§ 366$, Vida Conventual, p. 101).

2.2. A BUSCA DE FORRAGENS E A GUARDA DE POSIÇÕES. Nenhum irmão pode mandar gente às forragens ou à lenha sem autorização, até o respectivo comando para tal ter sido dado (a menos que vá fazê-lo tão perto que possa ouvir o alarme). Não deve mandar buscar a sela do cavalo sem permissão. Um irmão com dois escudeiros não deve enviar mais do 
que um deles; nem deve ir passear fora do acampamento, a menos que ouça o alarme ou a sineta. E os irmãos que estão a viver nas Casas em tempo de guerra não devem cavalgar no exterior, salvo se ouvirem o alarme onde estiverem. Nem em tempo de guerra nem de paz pode um irmão cavalgar uma légua sem autorização, nem sem botas, nem durante o dia no intervalo de duas refeições (§ 149, Estatutos Hierárquicos, “Como os Irmãos devem Instalar um Acampamento", p. 56). Quando estão no acampamento, os irmãos não devem sair por prazer sem autorização, salvo se estiverem num sítio em que possam ouvir a sineta (§ 376, Vida Conventual, p. 103).

2.3. AS RAÇÕES. As rações no acampamento são estabelecidas conforme a categoria dos homens: freires $>$ turcópolos $>$ sargentos $(\S 153$, Estatutos Hierárquicos, "Como os Irmãos devem Instalar um Acampamento", p. 57).

2.4. A REACÇÃO AO ALARME. Se o alarme soar no acampamento, aqueles que estão perto do grito [lançado pelo "crier": cf. § 149] devem abandonar essa zona com os seus escudos e lanças; e os outros irmãos devem ir para a capela para escutar as ordens. E se o alarme for dado fora do acampamento, não devem sair sem autorização, nem mesmo se se tratar de um leão ou de uma besta selvagem (§ 155, Estatutos Hierárquicos, ibid, p. 57$)^{27}$.

2.5. O ABASTECIMENTO. Quando estão no acampamento, os irmãos devem ter um comandante responsável pelo abastecimento (§ 366, Vida Conventual, p. 101).

2.6. LEVANTAR O ACAMPAMENTO. Quando chega o momento de levantar o acampamento, e se parecer bem ao Mestre e aos outros homens de valor que os seus homens dispersem, o Comandante da Terra deve indicar ao Marechal quantos homens devem ser colocados em cada uma das Casas ( 381 , ibid, p. 104). E o Marechal ou aquele que organiza isto deve dar a cada Casa um Comandante dos cavaleiros (§ 382, ibid, p. 104).

${ }^{27} \mathrm{O}$ assunto volta a ser considerado no $§ 380$ (Vida Conventual, p. 104), com algumas nuances: se o alarme for lançado fora do acampamento, devem sair sem autorização em direcção ao grito, qualquer que seja a razão pela qual tenha sido lançado. 


\section{A marcha: a partida, a coluna, as restrições de movimentos}

3.1. A SAÍDA DO CONVENTO. Quando o convento quer sair a cavalo, os irmãos não devem selar, nem carregar a bagagem, nem montar, nem deixar os seus lugares, a menos que o Marechal mande dar sinal para isso ou o ordene ( $§ 156$, Estatutos Hierárquicos, “Como os Irmãos formam a Linha de Marcha", p. 58).

3.2. A PARTIDA DO ACAMPAMENTO. Quando o Marechal tiver dado ordem para montar, os irmãos devem verificar se não estão a deixar nada esquecido no local do acampamento e, então, devem montar e seguir tranquilamente com a sua unidade, a passo ou a passo lento, com os escudeiros atrás deles, e devem posicionar-se na coluna de marcha se encontrarem um espaço para si e para os seus equipamentos. Quando se tiverem integrado na coluna de marcha, cada irmão deve dar ao seu escudeiro e ao respectivo equipamento um lugar à frente dele. $\mathrm{E}$, se for de noite, devem manter o silêncio. O irmão que se tiver já integrado na coluna de marcha pode ceder o lugar à sua frente a um outro irmão que ainda o não tenha feito, mas ninguém pode ceder o lugar atrás de si ( $§ 157$, Estatutos Hierárquicos, ibid, p. 58).

\subsection{CONTACTOS E MOVIMENTAÇÕES NA COLUNA DURANTE} A MARCHA. Se dois irmãos desejarem conversar um com o outro, o da frente é que deve procurar o de trás. E se algum irmão cavalgar fora da linha de marcha por motivos próprios, deve ir e regressar a favor do vento, para que o pó não fustigue a coluna de marcha. Se acontecer alguma coisa que faça com que um irmão não consiga ou não saiba como juntar-se à sua unidade, um dos irmãos deverá facultar-lhe um lugar à sua frente até ser de dia. Isto também se aplica aos escudeiros. E nenhum irmão deve cavalgar fora da coluna de marcha, seja por prazer seja para conversar, antes devem seguir atrás do seu equipamento, cada qual próximo da sua unidade e em silêncio (§ 158, Estatutos Hierárquicos, ibid, p. 58).

\subsection{AFASTAMENTO DA COLUNA E REACÇÃO AO ALARME.} Nenhum irmão deve abandonar a sua unidade para dar de beber aos seus cavalos ou por outro motivo, sem autorização. Se o alarme soar na coluna de marcha, os irmãos que estão juntos do grito podem montar nos seus cavalos e tomar os seus escudos e lanças, e devem manter-se calmos e esperar as ordens 
do Marechal; os outros devem encaminhar-se na direcção do Marechal para ouvir as suas ordens ( $§ 159$, Estatutos Hierárquicos, ibid, pp. 58-59).

3.5. REAGIR AOS IMPREVISTOS. Quando há guerra e os irmãos estão alojados numa estalagem ou instalados num acampamento, e o alarme for lançado, não devem partir sem autorização até que saia a bandeira; quando isso acontecer, devem seguir de imediato a bandeira e não devem armar nem desarmar sem permissão. Se estiverem deitados numa emboscada ou guardando uma pastagem, ou nalgum lado a fazer reconhecimento, ou deslocando-se de um lado para outro, não devem ir buscar as rédeas ou a sela ou alimentar os seus cavalos sem autorização ( $§ 160$, Estatutos Hierárquicos, ibid, p. 59).

3.6. ORGANIZAÇÃO DA COLUNA DE MARCHA. Quando o convento está em marcha, o Porta-Estandarte deve ir em frente da bandeira e deve ter um escudeiro ou guarda para a transportar, e deve encabeçar a coluna de marcha da maneira que o Marechal ordenar (§ 179, Estatutos Hierárquicos, "Retrais do Porta-Estandarte", p. 63).

\section{Os "esquadrões" - organização interna e principais regras}

4.1. O GRITO DE GUERRA. Quando é lançado o grito de guerra, os Comandantes das Casas devem reunir os seus cavalos e quando estes estiverem reunidos devem todos juntar-se ao esquadrão do Marechal, posto o que não devem abandoná-lo sem autorização. E todos os irmãos sargentos devem ir para junto do Turcopolier e não devem daí sair sem permissão. E todos os irmãos cavaleiros, todos os irmãos sargentos e os homens de armas ficam sob o comando do Marechal enquanto estiverem em armas (§ 103, Estatutos Hierárquicos, "Retrais do Marechal”, p. 45).

4.2. ORGANIZAÇÃO DO ESQUADRÃO. Quando está integrado num esquadrão, nenhum irmão deve ir de um esquadrão a outro, nem montar o seu cavalo nem tomar o seu escudo ou lança sem autorização; e quando está armado e segue num esquadrão, deve colocar os seus escudeiros com lanças em frente dele, e os escudeiros com cavalos atrás dele, da maneira que o Marechal ou aquele que está em seu lugar ordenar. Nenhum irmão deve virar a cabeça do seu cavalo para trás para lutar ou para gritar, ou por qualquer 
outra razão, enquanto estiver integrado num esquadrão ( $(161$, Estatutos Hierárquicos, "Como os Irmãos devem seguir num Esquadrão", p. 59).

4.3. ABANDONO DO ESQUADRÃO. Se algum irmão desejar testar o seu cavalo para saber o que é preciso ser feito ou para ver se há alguma coisa para ajustar na sela ou no pano, pode montar e sair por um breve espaço de tempo sem autorização e deve depois regressar rapidamente e em silêncio ao seu esquadrão. Se desejar tomar o seu escudo e lança, deve ter permissão para tal; e quem quer que deseje proteger a sua cabeça com a sua coifa de malha ${ }^{28}$ pode fazê-lo sem autorização; mas não a pode retirar. Nenhum irmão pode carregar ou abandonar as fileiras sem permissão ( $§ 162$, Estatutos Hierárquicos, ibid, p. 59). E se por acaso acontecer que algum cristão tem um comportamento tolo e algum Turco o ataca para o matar e ele se acha em perigo de morte, e algum irmão que está nessa zona desejar abandonar o seu esquadrão para o socorrer e a sua consciência lhe disser que o pode ajudar, poderá fazê-lo sem autorização, regressando depois tranquilamente e em silêncio. Se ele carregar ou abandonar o esquadrão será feita justiça tão severa quanto mandá-lo regressar a pé ao acampamento ${ }^{29}$ ou tomar-lhe tudo, excepto o seu hábito ( $\$ 163$, Estatutos Hierárquicos, ibid, p. 59).

4.4. ACÇÃO DO TURCOPOLIER E DO PORTA-ESTANDARTE. Quando os esquadrões do convento são formados em linha, o Turcopolier deve manter os seus homens no esquadrão e ser como os outros, e deve comportar-se como se carregasse a bandeira. Nem deve carregar ou atacar, a menos que o Mestre ou o Marechal assim lho ordenem ( $§ 170$, Estatutos Hierárquicos, "Retrais do Turcopolier", p. 61). E em tempo de guerra, quando os irmãos avançam em esquadrões, um turcópolo deve conduzir a bandeira e o Porta-Estandarte deve dispor os escudeiros num esquadrão (§ 179, Estatutos Hierárquicos, "Retrais do Porta-Estandarte, p. 63).

${ }^{28}$ Inicialmente, a coifa era parte integrante do hauberk, mas no séc. XIII tornou-se num capuz de malha separado (UPTON-WARD - The Rule of the Templars..., n. 162.1, p. 59). Cf. também supra: nota 23.

${ }^{29}$ Uma desgraça especial para um cavaleiro, que se definia a si próprio como um guerreiro montado (UPTON-WARD - The Rule of the Templars..., n. 163.1, p. 59). 


\section{A carga de cavalaria}

5.1. O PROCEDIMENTO BASE. Quando o Marechal desejar tomar do Sub-Marechal a bandeira, o Sub-Marechal deve juntar-se ao Turcopolier (caso o Marechal o não retenha). E então o Marechal deve designar entre cinco e 10 irmãos cavaleiros para o guardar a ele e à sua bandeira; e estes irmãos devem submergir os seus inimigos, todos à volta da bandeira, com toda a sua destreza, e não devem abandonar ou ir embora, antes devem ficar tão perto da bandeira quanto lhes for possível para que, se necessário, a possam socorrer. E os outros irmãos podem atacar à frente e atrás, para a esquerda e para a direita, e onde quer que entendam que podem atormentar os inimigos de maneira a que, se a bandeira precisar deles, a possam ajudar, e a bandeira a eles, se for caso disso (§ 164, Estatutos Hierárquicos, "Como os Irmãos devem seguir num Esquadrão", pp. 59-60).

5.2. O USO DA BANDEIRA. O Marechal deve ordenar ao Comandante dos Cavaleiros (o qual deve ser um dos 10 cavaleiros referidos atrás) que transporte uma bandeira enrolada à volta da sua lança. E este irmão não deve abandonar o Marechal, antes deve manter-se tão perto dele quanto possível, de tal modo que, se a bandeira do Marechal tombar, ou se rasgar, ou the acontecer alguma desgraça, ele possa desfraldar a sua; ou se não, ele deve actuar de tal modo que os irmãos possam reunir-se em volta da sua bandeira caso seja necessário. Se o Marechal for ferido tão gravemente ou estiver tão magoado que não possa conduzir o ataque, aquele que transporta a bandeira enrolada deverá liderar o ataque. E aqueles que tiverem sido destacados para guardar a bandeira deverão ir com ele; nem o Marechal, nem aquele que carrega a bandeira enrolada na batalha deve carregar com ela, ou deve baixá-la para carregar, qualquer que seja a razão $(\S 165$, Estatutos Hierárquicos, ibid, p. 60).

5.3. LIDERANÇA E ABANDONO DO ESQUADRÃO. Aqueles que lideram um esquadrão de cavaleiros não devem carregar ou abandonar o esquadrão, a menos que o façam com permissão ou consentimento do Mestre ou de quem o substituir. Cada comandante de esquadrão pode ter uma bandeira enrolada e pode comandar até 10 cavaleiros, para o guardarem a si e à bandeira. Tudo o foi dito atrás para o Marechal é válido para os comandantes que lideram os esquadrões ( $§ 166$, Estatutos Hierárquicos, ibid, p. 60). 
5.4. REAGRUPAMENTO. Se algum irmão não conseguir avançar em direcção à sua bandeira porque se adiantou excessivamente com receio dos muçulmanos que estão entre ele e a bandeira, ou porque não sabe o que aconteceu com ela, deverá juntar-se à primeira bandeira cristã que encontrar. E se achar a bandeira do Hospital, deverá permanecer junto dela e informar o líder do esquadrão ou outra pessoa de que não pode reunir-se à sua bandeira, e deve permanecer tranquilo e silencioso até se poder juntar a ela. Tão-pouco deve abandonar o seu esquadrão devido a ferimentos ou a cortes, sem permissão; e se estiver tão gravemente ferido que não possa requerer autorização, deve enviar um irmão para esse efeito (§ 167, Estatutos Hierárquicos, ibid, p. 60).

\subsection{DERROTA E ABANDONO DO CAMPO DE BATALHA.} Se acontecer que os cristãos são derrotados, nenhum irmão deve abandonar o campo de batalha para regressar à guarnição enquanto ainda houver alguma bandeira malhada ao alto; se partir, será expulso para sempre da sua Casa. Se ele verificar que já não há recurso, deve juntar-se à bandeira do Hospital mais próxima, ou a alguma outra bandeira cristã, se as houver, e quando esta(s) bandeira(s) forem derrotada(s), então sim, o irmão poderá seguir rumo à guarnição a que Deus o conduzir ( $§ 168$, Estatutos Hierárquicos, ibid, p. 60) ${ }^{30}$.

5.6. O PAPEL DESTINADO AOS IRMÃOS SARGENTOS. Quando em armas, ficam sob o comando do Turcopolier. Os irmãos sargentos que estão equipados com malha metálica devem actuar em combate tal como os freires cavaleiros. Os restantes sargentos (não tão bem equipados) se tiverem um bom desempenho receberão graças de Deus e dos irmãos; e se virem que não podem resistir ou que estão feridos, podem ir para trás sem autorização e sem perigo para a Casa. Se houver irmãos destacados para comandar os sargentos em armas, estes não devem partir para a carga (ou por qualquer outro motivo) sem autorização. Mas se o Marechal ou os irmãos carregarem, devem conduzir os sargentos alinhados em fileiras cerradas atrás deles, com toda a sua destreza, de tal maneira que, se os irmãos necessitarem deles,

\footnotetext{
${ }^{30}$ Repete a ideia no $§ 421$ (“A Realização de Capítulos Ordinários”), acrescentando que "é bom que os nossos irmãos permaneçam todos juntos, caso possam, seja com bandeira, seja sem ela” (p. 113).
} 
os sargentos possam vir em seu auxílio (§ 172, Estatutos Hierárquicos, "Retrais do Turcopolier", p. 61).

5.7. A ACÇÃO DO PORTA-ESTANDARTE. O Porta-Estandarte deve dispor os escudeiros num esquadrão. Se o Marechal e os irmãos carregarem, os escudeiros que conduzem os destriers ${ }^{31}$ devem carregar atrás dos seus senhores, e os outros devem tomar as mulas que os senhores conduziam e permanecer junto do Porta-Estandarte. Este deve ter uma bandeira enrolada à volta da sua lança e, quando o Marechal carregar, deve ter os escudeiros formados em esquadrões e deve desfraldar a sua bandeira; e deve ir atrás daqueles que atacam, tão bem, tão depressa e de maneira tão organizada quanto puder, a passo ou a passo lento, ou da forma que lhe parecer melhor (§ 179, Estatutos Hierárquicos, “Retrais do Porta-Estandarte”, p. 63).

\section{As características do equipamento militar}

6.1. OURO E PRATA. É proibido usar ouro ou prata nas rédeas, nos estribos ou nas esporas. Só mesmo se receberem de alguém um arnês a título de caridade, o qual seja tão velho que já mal se note o ouro ou a prata (§ 52, Regra Primitiva, p. 32) 32 .

6.2. COBERTURAS DE ARMAS. Ninguém deve ter uma cobertura para o seu escudo ou para a sua lança, pois isso até pode ser prejudicial $(\S 53$, ibid, p. 32) 33 .

6.3. CORREIAS. Ninguém deve encurtar as correias de couro dos seus estribos, nem a sua cilha, nem o cinto da sua espada, embora possa ajustar a fivela sem autorização ( $§ 144$, Estatutos Hierárquicos, "Retrais dos irmãos cavaleiros e dos irmãos sargentos”, p. 55) ${ }^{34}$.

${ }^{31}$ Destriers: cavalos de guerra que eram levados pelos escudeiros e montados pelos cavaleiros apenas quando a batalha começava (UPTON-WARD, The Rule of the Templars..., n. 179.1, p. 63$)$.

${ }^{32}$ Era habitual os cavaleiros decorarem as suas rédeas com pequenas placas de metal (Idem, ibid, n. 52.1, p. 32).

${ }^{33}$ Mas aos Cavaleiros Teutónicos era ordenado que conservassem as pontas das suas lanças cobertas, de maneira a preservá-las polidas e afiadas (UPTON-WARD, The Rule of the Templars..., n. 53.1, p. 32).

${ }^{34}$ Segundo UPTON-WARD (ibid, n. 144.1, p. 55), encurtar os estribos implicava combater com a espada, mais do que com a lança, i.é. em corpo-a-corpo, pois o cavaleiro 
6.4. GANTELETES. Cada irmão deve vestir ganteletes [defesas de braço] quando tiver vestido o seu gibão de maneira a equipar-se com armas [para o combate]; de outro modo, não deve vesti-los sem autorização (§ 325, Vida Conventual, p. 92).

\section{Manutenção de cavalos e equipamento; alienações}

7.1. OBTENÇÃO, SUBSTITUIÇÃO E PERDA DE CAVALOS. Os cavaleiros seculares que desejarem servir a Casa do Templo por um período determinado devem adquirir um cavalo conveniente e armas. Devem pôr um preço no cavalo, por escrito; e devem deixar que tudo aquilo de que o cavaleiro, o seu escudeiro e o cavalo necessitam seja dado por caridade fraternal, de acordo com os meios da Casa. Se o cavalo morrer ao serviço da Casa, o Mestre substitui-lo-á, caso possa. Se, no final do seu tempo de serviço, o cavaleiro quiser regressar ao seu país, deve deixar na Casa metade do preço do cavalo e a outra metade pode recebê-la a partir das esmolas da Casa (§ 66, Regra Primitiva, p. 35). Quando chegam cavalos de além-mar [i.é. do Ocidente] devem ser colocados na caravana do Marechal, mas o Mestre pode tomar algum se quiser (e pode dá-lo a gente amiga da Casa). Se oferecerem algum cavalo ao Mestre, este poderá dá-lo a um irmão à sua escolha. E o Mestre pode tomar qualquer cavalo que queira a qualquer um dos irmãos ( $\$ 84$, Estatutos Hierárquicos, “Retrais do Mestre”, p. 40). O Senescal pode dar a um amigo de confiança um palafrém, uma mula de qualquer sexo ou um cavalo de sela, entre outras prendas, mas sob conselho dos irmãos (§ 100, Estatutos Hierárquicos, "Retrais do Senescal”, p. 44). Se um irmão emprestar o seu cavalo a outro irmão em algum lugar onde ele não possa ir sem autorização, e o cavalo se perder, ou morrer, ou for ferido, o hábito desse irmão ficará à consideração do colectivo (§251, Penitências, "Penitências que levam à perda do hábito", p. 77; repetido no $\S 600$, Detalhes Suplementares sobre Penitências, p. 155). Se um irmão matar ou ferir um cavalo, ou o perder por culpa sua, o seu hábito ficará igualmente nas mãos

podia então erguer-se nos estribos para desferir um golpe; apertar a cilha implicava prontidão para actuar. 
dos irmãos do convento (§ 251, Penitências, "Penitências que levam à perda do hábito", p. 77). Se um irmão estiver fornecido com os cavalos de um outro irmão e este encontrar os seus cavalos numa batalha poderá tomá-los como seus ( $§ 630$, Detalhes Suplementares sobre Penitências, p. 162).

7.2. ALIENAÇÃO DE ARMAS. Todas as armas podem ser dadas, excepto espadas, lanças e cotas de malha: estas não podem ser alienadas (§ 82, Estatutos Hierárquicos, "Retrais do Mestre", p. 40).

7.3. MANUTENÇÃO DE CAVALOS E ARMAS. Quando os irmãos acabarem de rezar as Matinas, cada qual deve ir ver o seu equipamento e os seus cavalos, caso possam fazê-lo; e se houver alguma coisa para corrigir, devem fazê-lo (§ 283, Vida Conventual, p. 82). Quando tiverem sido cantadas as Completas, cada irmão deve ir ver o seu cavalo e equipamento ( $§ 305$, ibid, p. 87). Cada irmão deve cuidar zelosamente do seu equipamento e cavalos. Nenhum irmão deve fazer correr o seu cavalo se este não estiver descansado, nem galopar sem autorização (§ 315, ibid, p. 89). Nenhum irmão deve carregar o seu hauberk ou a sua meia-calça de malha metálica numa mala [normal], mas sim numa mala de couro ou de corda entrelaçada. (§ 322, ibid, p. 91). Nenhum irmão pode arremessar a sua lança sem autorização, nem pode reparar a sua espada sem permissão, nem o seu chapéu-de-ferro ou a cota de malha, nem atirar o seu chapéu-de-ferro (§324, ibid, p. 91). Nenhum irmão, seja no acampamento ou fora dele, pode emprestar sem autorização o seu cavalo a outro irmão ou a alguém para este sair para longe por prazer. Nenhum irmão deve deixar os seus cavalos agrilhoados ou açaimados em qualquer lugar durante a noite sem autorização (§ 377 , ibid, p. 103). Quando os irmãos têm autorização para cuidar dos seus cavalos e animais durante a noite, nenhum deve deixar posta a coberta no seu cavalo, a menos que a autorização o tenha mencionado (§ 378, ibid, p. 103). As coisas que um irmão não deve levar consigo, quando sai da casa: ouro, prata ou armas - chapéu-de-ferro, sobrecota, gibão, hauberk, cota de malha sem mangas, espada, lança, escudo, maça turca, punhal de armas, meia-calça de malha, armas turcas e, em síntese, tudo aquilo que está incluído nestas palavras: 'nada que pertença às armas’ (§ 427, A Realização de Capítulos Ordinários, p. 114). O irmão que estiver a cumprir penitência não deverá cuidar do seu equipamento; e o irmão a quem ele o confiou deve cuidar dele como se fosse seu (§ 510, ibid, pp. 133-134). 


\section{O Treino Militar ${ }^{35}$}

8.1. A CAÇA. É proibido caçar um pássaro com outro pássaro [falcoaria], pois um homem de religião não deve sucumbir aos prazeres ( $§ 55$, Regra Primitiva, p. 32). Recomenda-se aos freires que não vão para as florestas caçar animais com arco ou com besta; nem devem ir atrás de cães, nem esporear um cavalo com desejo de capturar uma besta selvagem $(\S 55$, ibid, pp. 32-33). Todavia, a proibição de caçar não inclui o leão (§ 56, ibid, p. 33). Se um irmão caçar e daí resultar dano, o seu hábito ficará à consideração dos outros (§ 256, Penitências, "Penitências que levam à perda do hábito", p. 77; repetido no $\S 601$, Detalhes Suplementares sobre Penitências, p. 155).

8.2. EXERCÍCIOS, RISCOS E CASTIGOS. Ninguém deve dar autorização para derramar sangue, nem para correr cavalos, nem para nadar ou para justar no lugar onde está o Mestre, a não ser o próprio Mestre (§ 95, Estatutos Hierárquicos, "Retrais do Mestre, p. 43). Se um irmão testar as suas armas e equipamento e daí resultar dano, o hábito fica à consideração do colectivo (§ 257, Penitências, "Penitências que levam à perda do hábito", p. 77; repete no $\S 601$, Detalhes Suplementares sobre Penitências, p. 155). Se um irmão não transporta uma besta e deseja cavalgar um cavalo na 'pista', pode correr o seu cavalo durante uma, duas ou três pistas sem permissão. Nenhum irmão deve correr impetuosamente o seu cavalo contra outra pessoa durante mais do que meia-pista sem autorização. Nenhum irmão deve correr o seu cavalo durante uma pista completa, nem carregar armas em meia-calça de malha sem permissão; mas poderá fazê-lo durante meia-pista. Quando os irmãos saem com intenção de correr uma pista, devem calçar as suas botas. Quando os irmãos justam, não devem arremessar lanças, pois isso é proibido por causa das feridas que daí podem resultar (§ 315, Vida Conventual, p. 89).

8.3. APOSTAS E JOGOS. Ninguém deve fazer apostas, nem num cavalo nem em nenhuma outra coisa, excepto uma flecha sem ferro, ou algo que não lhe custe a si (ou a outro) dinheiro (p. ex: uma lanterna de campo; um malho de madeira; estacas de tendas). E cada irmão pode apostar contra

${ }^{35}$ Os Templários não tinham propriamente um programa de treino, pois partia-se do princípio de que os freires já tinham alguma perícia na arte da guerra no momento em que entravam para a Ordem (UPTON-WARD, The Rule of the Templars..., n. 14.2, p. 23). 
outro irmão, com a sua bèsta, 10 velas sem autorização, mas não mais; e pode apostar a corda falsa da sua bèsta pelas velas; mas sob pretexto algum deve deixar a corda [montada] durante a noite sem autorização. E o irmão não pode nem deve colocar outra aposta na tensão de uma besta. Nenhum irmão deve jogar a não ser "marelles"36, por prazer e sem apostas; nenhum deve jogar xadrez, gamão ou "eschaçons" (§ 317, Vida Conventual, pp. 89-90).

\section{Principais punições por desobediência militar}

9.1. FUGA E ABANDONO DA BANDEIRA. Se um irmão abandonar a sua bandeira e fugir com medo dos Sarracenos, será expulso da casa (§ 232, Penitências, "Penitências que originam expulsão da Casa", p. 74; repete no § 419, A realização de Capítulos Ordinários, p. 419, onde explicita que isto inclui não só os irmãos cavaleiros mas também os irmãos sargentos quando armados com espadas; o $\S 420$, p. 113, acrescenta que se suceder que o irmão cavaleiro e o irmão sargento estiverem ambos sem espadas devem permanecer assim junto à bandeira, todos juntos, pois nenhum deles deverá abandonar a posição enquanto houver uma bandeira malhada no ar).

9.2. ABAIXAR A BANDEIRA. Se um irmão do Templo que carrega a bandeira na batalha a baixar para golpear, sem que daí resulte dano, o hábito dele fica ao arbítrio dos monges; mas se daí resultar dano colectivo, pode não conservar o hábito e pode ser decidido pô-lo a ferros; pode nunca mais transportar a bandeira ou ser comandante em batalha $(\S 241$, Penitências, "Penitências que levam à perda do hábito", p. 75; repete no $\S$ 611, Detalhes Suplementares sobre Penitências, p. 157, onde se explicita o sentido da punição: "É que se a bandeira é rebaixada, aqueles que estão longe não sabem porque razão isso aconteceu, para o bem ou para o mal, pois um Turco pode mais facilmente tomá-la ou capturá-la quando ela está em baixo do que quando está ao alto; e homens que perdem a sua bandeira têm muito medo, e podem sofrer uma grande derrota, e é por causa deste medo que isto é tão rigorosamente proibido".

${ }^{36}$ Segundo UPTON-WARD (ibid, n. 317.1, p. 90), parece ser um jogo de tabuleiro com fichas. 
9.3. CARREGAR SEM PERMISSÃO. Se um irmão que leva a bandeira carregar sem permissão daquele que a pode dar, não estando nesse momento cercado ou num lugar em que não possa obter autorização, o hábito fica à consideração dos outros irmãos; mas se deste comportamento resultar dano grave, pode ser decidido pô-lo a ferros e pode nunca mais transportar a bandeira ou ser comandante em batalha ( $§ 242$, Penitências, "Penitências que levam à perda do hábito", p. 75; repete no $\S 612$, Detalhes Suplementares sobre Penitências, p. 157). Se um [outro] irmão que está na batalha carregar sem autorização e daí resultar dano, o hábito fica à consideração dos irmãos. Mas se ele vir um cristão em perigo de vida e a sua consciência o mandar socorrê-lo, tal como vem no "Retrais" (§ 163), pode fazê-lo. Mas "em nenhuma outra circunstância deve um irmão do Templo carregar sem permissão" (§ 243, Penitências, "Penitências que levam à perda do hábito", p. 75; repete o essencial no $\S 613$, Detalhes Suplementares sobre Penitências, p. 157).

9.4. CUMPRIMENTO DE PENAS. Nenhum irmão que esteja a cumprir penitência no chão [i.é. a comer no chão e não na mesa comunitária] deve tocar em armas, a menos que caiam em desespero em algum lado e o assunto não possa ser resolvido de outra maneira. Mas nem o Mestre nem ninguém podem emprestar-lhe cavalos ou armas, nem dar-lhe autorização para os tomar, sem o consentimento dos irmãos ( $\$ 501$, A Realização de Capítulos Ordinários, p. 131). Se um irmão estiver em penitência com todo o seu hábito e soar o alarme, ele poderá receber de empréstimo cavalos e armas de modo a acorrer a esta tarefa com os outros irmãos, mas quando regressar deve voltar para a sua penitência (§ 656, Detalhes Suplementares sobre Penitências, p. 167).

\section{Comentário final}

Os artigos que evocámos mostram o extraordinário nível de organização e de disciplina militar a que os Templários estavam sujeitos. São impressionantes os detalhes sobre a conservação das montadas e das armas, sobre a organização das colunas de marcha, sobre o uso das bandeiras, sobre a constituição dos esquadrões de combate e, acima de tudo, sobre os procedimentos de carga da cavalaria pesada. Não foi por acaso que 
os exércitos cruzados se acostumaram a colocar os Templários e os Hospitalários na vanguarda ou na retaguarda das colunas de marcha (as zonas mais vulneráveis de um exército em trânsito). E quando assim não actuavam, não raro se arrependiam. Veja-se o que sucedeu com Luís VII de França quando, em 1147, negligenciou a disciplina da sua coluna de marcha permitindo que a vanguarda se distanciasse do resto do exército para acampar: foi duramente castigado pelos Turcos em Cadmos (na Ásia Menor) e viu-se forçado a entregar o comando das operações ao Mestre do Templo, Evérard de Barres.

Alguns historiadores, como John France ${ }^{37}$, admitem que a carga cerrada da cavalaria pesada (uma manobra exigente) possa ter sido uma inovação dos exércitos cristãos da Síria-Palestina. Pelo menos aquela carga organizada em pequenos esquadrões ("conrois") muito unidos, devastadora, perfeita em todas as fases da sua execução, capaz de sobreviver para além do primeiro contacto e da penetração, e até de reagrupar para carregar de novo em sentido inverso. Talvez possamos sugerir algumas excepções a esta intuição do especialista de Swansea (incluindo alguns casos ibéricos, como Las Navas de Tolosa-1212 ou Jerez-1231). Até porque as Ordens Militares também intervinham no Ocidente e as Regras eram as mesmas... Mas percebe-se a ideia de fundo: só na Terra Santa era obrigatório alcançar o grau de profissionalismo que a Règle du Temple sugere. Aí, num terreno árduo (o deserto, o calor, a falta de água), perante um inimigo muito superior em números e extremamente ardiloso, todo o erro era fatal. Além disso, Templários e Hospitalários actuavam em grupos homogéneos, sempre disponíveis e alertas, firmes até final, muito treinados e que se conservavam activos durante muitos anos, o que lhes garantia uma coesão e uma continuidade ímpares. E viviam numa atmosfera de obediência e de humildade monásticas que os tornava muito mais eficazes do que os exércitos feudais do Ocidente, compostos por cavaleiros aguerridos mas individualistas, propensos ao saque, à perseguição descontrolada e às façanhas pessoais, em detrimento dos interesses colectivos. Quantos exemplos de desastres no Ocidente não poderíamos citar a este respeito!

${ }^{37}$ FRANCE, John - A Changing Balance: Cavalry and Infantry, 1000-1300. Revista de História das Ideias, 30 (2009), 163. 
Cargas como a de Balduíno IV em Montgisard (em 1177), com uma forte componente de Templários, contra a muito mais numerosa hoste de Saladino, raramente ocorriam em França, em Itália ou na Inglaterra. Quantas colunas, em ambiente europeu, poderiam ser tão sólidas, pacientes e eficazes quanto a de Ricardo Coração-de-Leão em 1191, quando marchava entre Jafa e Acre sob o fogo e a provocação cerradas dos arqueiros montados de Saladino?...

Claro que a Règle era uma referência (ainda que sagrada) e os seus intérpretes eram humanos. Por isso também falhavam. É clássico citar o exemplo de Gérard de Ridefort, o Mestre do Templo que ficou ligado ao mais dramático desastre dos exércitos latinos no Oriente: a batalha de Hattin, em Julho de 1187. A sua deficiente avaliação das diversas cambiantes da situação, a sua recusa em escutar aqueles que o aconselhavam, o seu voluntarismo, levaram-no a tomar decisões precipitadas que lesaram gravemente as possessões territoriais latinas na Síria-Palestina e conduziram à perda da Cidade Santa e de grande parte do Reino de Jerusalém.

Outras vezes, os Templários viam-se integrados em exércitos cristãos mais vastos, vindos do Ocidente e sujeitos ao comando de terceiros. Quando assim sucedia, não raro eles se viam envolvidos em aventuras irresponsáveis como aquela que levou Roberto de Artois (irmão de Luís IX de França), em 1250, a um combate suicida nas ruelas de Mansurá (no Egipto). Todavia, mesmo aí os corpos das Ordens conseguiam provar toda a sua competência militar: se Baybars (o líder dos Mamelucos) não tirou, no dia seguinte, um partido trágico do desastre do conde de Artois em Mansurá, foi justamente porque o Mestre do Templo, Guillaume de Sonnac, teve o controlo emocional suficiente para se opor a isso, organizando as tropas remanescentes e conduzindo-as (à custa da sua própria vida) com uma disciplina e uma coragem que evitaram males maiores.

A Regra do Templo - um texto para ler e meditar. Com o espírito crítico e as cautelas próprias de qualquer texto medieval. Mas também com grande admiração por uma pequena máquina de guerra altamente hierarquizada e profissional que foi decisiva para manter um território distante e ingrato sob o domínio cristão, durante mais de um século e meio. Esperamos ter contribuído para tornar este texto de referência mais acessível ao público de língua portuguesa que se interessa pela temática tão apaixonante e multifacetada da arte da guerra no mundo medieval. 